6. Чайковский И.И., Кадебская О.И. Минеральные образования подземных горячих источников Баксанской нейтринной обсерватории (г. Курмутау, Приэльбрусье) // Проблемы минералогии, петрографии и металлогении: науч. чтения памяти П.Н. Чирвинского / ПГНИУ [и др.]. - Пермь, 2016. Вып. 19. - С. 66-80.

7. Наумкин Д.В., Осетрова О.И. Палеонтологическая коллекция музея карста и спелеологии Горного института УрО РАН. Создание постоянной выставки // Грибушинские чтения - 2019. Кунгурский диалог: тез. докл ХІ Междунар. соц.-культ. форума. - Пермь, 2019. - С. 513-519.

8. Михайлова И.А., Бондаренко О.Б. Палеонтология: учебник для вузов. - 2-е изд., перераб. и доп. - М.: МГУ, 2006. - 592 с.: ил.

9. Naumkin D.V. Promysla - a location of marine invertebrates during middle-upper ordovicien period (perm region) // Science and Society: 14th International Scientific and Practical Conference, 27-29 November 2019. - London, 2019. - P. 44-51.

10. Шунтов В.П. Зигзаги рыбохозяйственной науки (Субъективные заметки). - Владивосток: Изд. центр ТИНРО, 1994. $-367 \mathrm{c}$.

\title{
НЕКОТОРЫЕ МИНЕРАЛОГО-ТЕХНОЛОГИЧЕСКИЕ ОСОБЕННОСТИ НЕФТЕТИТАНОВЫХ РУД МЕСТОРОЖДЕНИЯ ЯРЕГА
}

\author{
А.Ф. Сметанников, О.В. Коротченкова, Д.В. Оносов \\ Горный институт УрО РАН, г. Пермь
}

\begin{abstract}
Аннотация: Рассматриваются особенности проявления в нефтетитановых рудах регенерированных титановых минералов, образование которых обусловлено проявлением пострудных процессов. Высказывается мнение о возможности влияния термических процессов на изменение состава продуктов флотационного обогащения нефтетитановой руды.

Ключевые слова: нефтетитановые руды, диоксиды титана, регенерация, флотоконцентрат, кварц, высокотемпературный обжиг, сульфиды, обогащение, монацит, ксенотим.
\end{abstract}

\section{Введение}

Нефтетитановая руда представляет собой мелко и среднезернистый кварцевый песчаник, с вкраплениями кварц-лейкоксенового агрегата и пропиткой тяжелой нефтью. Выделяется два типа руд.

В основном типе, представленном тонковкрапленными рудами, отмечены обособления (2 тип руд) представленные агрегатом сульфидов, диоксидов титана в срастании с кварцем и агрегатов тех же минералов, но с признаками регенерации, которая выражается в изменении состава диоксидов титана, с уменьшением содержания компонентов представляющих вредные примеси ( $\mathrm{Al}, \mathrm{Si}$, и др.).

Выделяется несколько типов агрегатов титановых и сопутствующих им минералов.

Это агрегаты кварц-лейкоксенового состава, агрегаты того же состава, но со следами регенерации, которая выражается в формировании в пределах этих агрегатов диоксидов титана без вкраплений кварца. Кроме того, формируются агрегаты диоксидов титана совместно с сульфидами и монацитом, где сульфид является цементом, агрегаты титановых минералов, где наряду с реликтами лейкоксеновых выделений, присутствуют регенерированные диоксиды титана, с вкраплениями монацита, ксенотима, циркона, в сульфидном цементе, КПШ, силикатов $\mathrm{Fe}, \mathrm{Na}, \mathrm{Mg}$ и выделениями кварца. Отмечены и самостоятельные выделения циркона, монацита и ксенотима, также в сульфидном цементе, но распространение их ограничено.

Процесс регенерации диоксидов титана и образование регенерированных диоксидов титана связывается с процессом преобразования, проявленным в нефтетитановых рудах [1]. 


\section{Результаты исследований}

Изучались обособления, относящиеся к 2 ту руд. Проводились морфоструктурные исследования обособлений и микрозондовый анализ исходных кварц-лейкоксеновых агрегатов, регенерированных агрегатов и переотложенных диоксидов титана.

На рис. 1 показан кварц-лейкоксеновый агрегат. На рис. 2 показан участок кварцлейкоксенового агрегата, где отчетливо видна пойкилитовая структура агрегата. Пирит образует индивидуализированные выделения. В кварце отмечаются выделения органического вещества.

Видно, что размер отдельных участков зерен 20х20 микрон, это агрегат кварца и диоксида титана. Т.е. если сравнивать с флотоконцентратом (продукт ЗАО «СИТТЕК»), грансостав которого 0,315 мм (размер отдельных зерен) - кварц не освобождается из сростков инаходится в срастании с диоксидом титана. На рис. 3,4 показан еще один кварц-лейкоксеновый агрегат с включениями КПШ в кварце, пирита и монацита. Хорошо виден характер взаимоотношений кварца и титанового минерала (срастания).

Микрозондовые анализы «чистых» (от кварца) участков диоксида титана показывают наличие примесей $\mathrm{Fe}, \mathrm{Si}, \mathrm{K}, \mathrm{Al}, \mathrm{V}$ (табл. 1) - анализы диоксида титана исходного.

На рис. 5 показан агрегат диоксида титана (G1), с включениями пирита (G2) и монацита (G3). Отчетливо видны блоки кварц-лейкоксенового агрегата (микропойкилитовая структура). Видны также регенерированные участки диоксида титана, свободные от «вростков» кварца.

На рис. 6 показан детальный участок с остаточными блоками кварц-лейкоксенового агрегата и регенерированными участками, представленными диоксидами титана, свободными от включений кварца и, в свою очередь, с более поздними включениями пирита, монацита и ксенотима.

Микрозондовый анализ регенерированных участков (диоксид титана регенерированный) показывает наличие примесей $\mathrm{Fe}, \mathrm{Si}$ при полном отсутствии Al, K, V (табл.1).

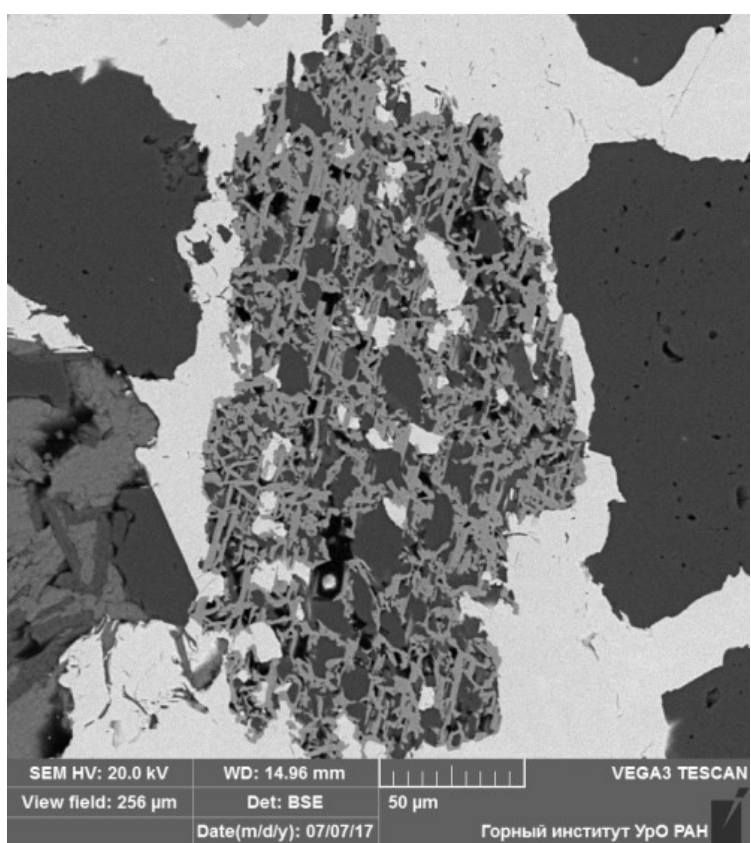

Рис. 1.

Кварц-лейкоксеновый агрегат. Изображение в отраженных электронах

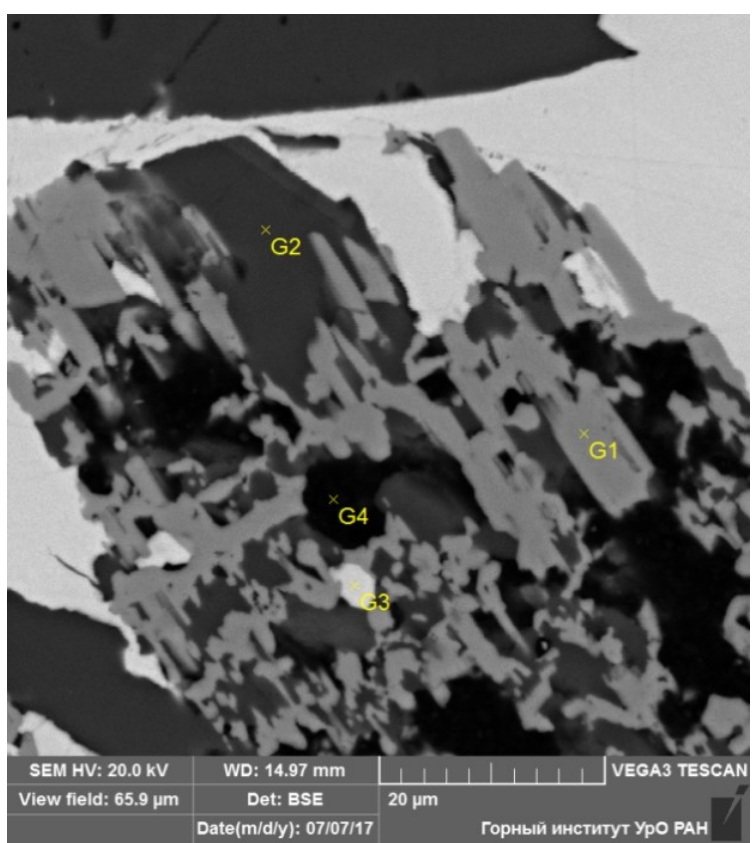

Рис. 2. Кварц-лейкоксеновый агрегат (деталь). Диоксид титана (G1), кварц (G2), пирит (G3), органика (G4). Изображение в отраженных электронах 


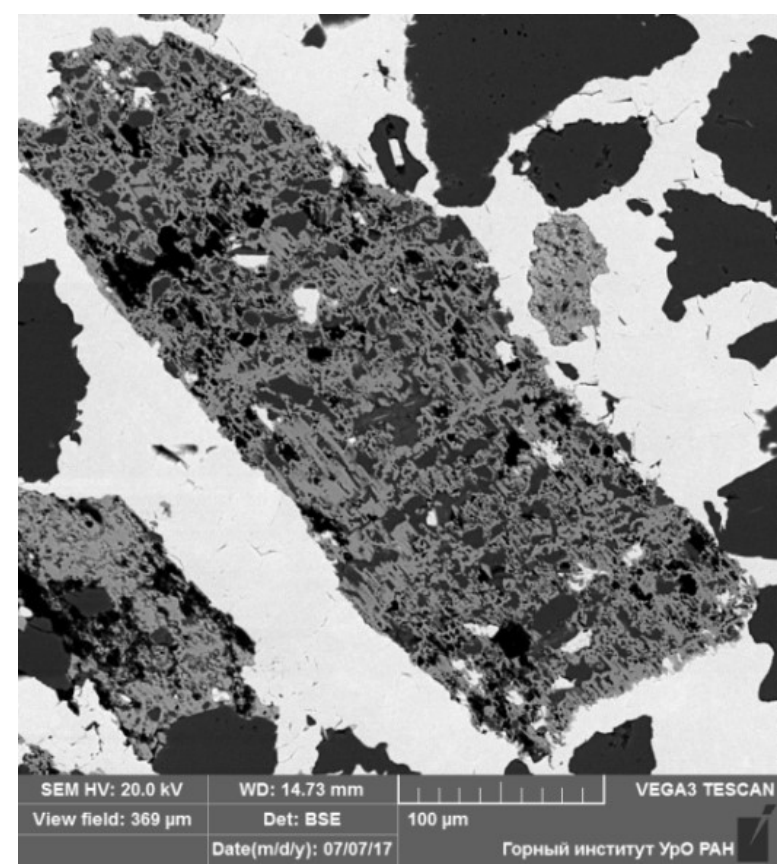

Рис. 3. Зерно кварц-лейкоксенового агрегата в сульфидном цементе.

Изображение в отраженных электронах

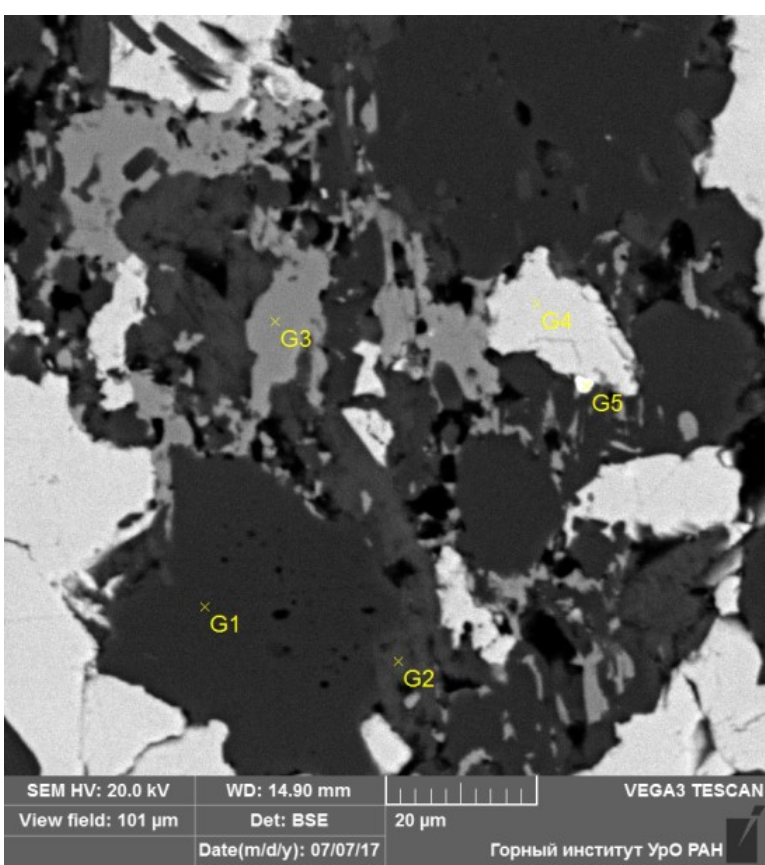

Рис. 4. Деталь: кварц (G1), силикат $\mathrm{Al}, \mathrm{Si}, \mathrm{K}, \mathrm{Fe}$ (G2), диоксид титана (G3), пирит (G4), монацит (G5). Изображение в отраженных электронах

На рис. 7, показано обособление, представляющее собой агрегат титановых минералов, рутила, пирита и кварца.

На рис. 8 детальный участок, где видно, что это агрегат регенерированных минералов титана и реликтовых выделений кварца: диоксид титана (G1, G3), рутил $(\mathrm{G} 2)$, кварц (G4), кварц (G5), пирит (G6).

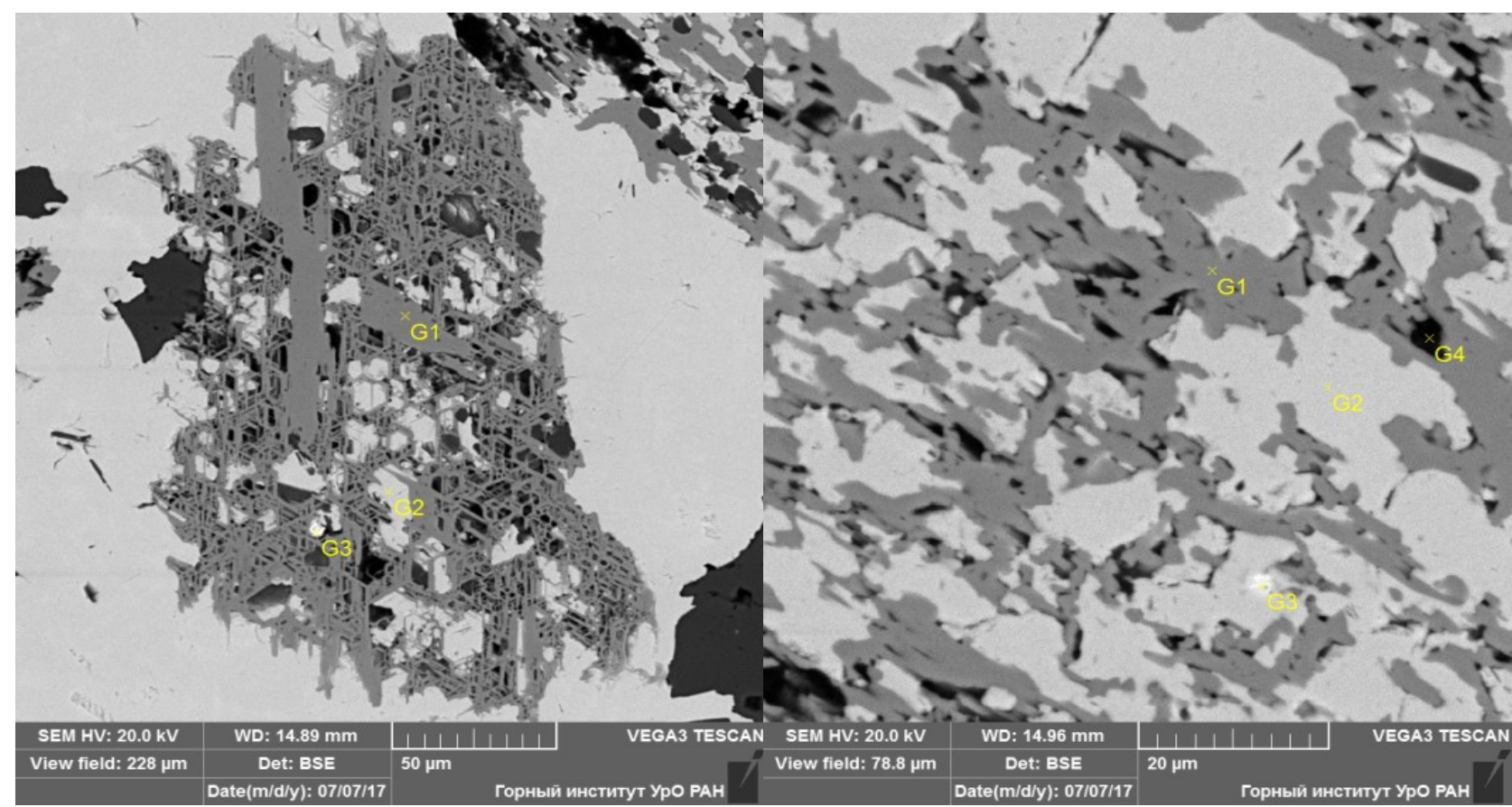

Рис. 5. Кварц-лейкоксеновый агрегат с включениями пирита (G2), и монацита (G3). Регенерированные участки диоксида титана (G1). Изображение в отраженных электронах
Рис. 6. Участок кварц-лейкосенового агрегата. Диоксид титана (G1), кварц (G2), ксенотим (G3), включения органики (G4). Изображение в отраженных электронах 


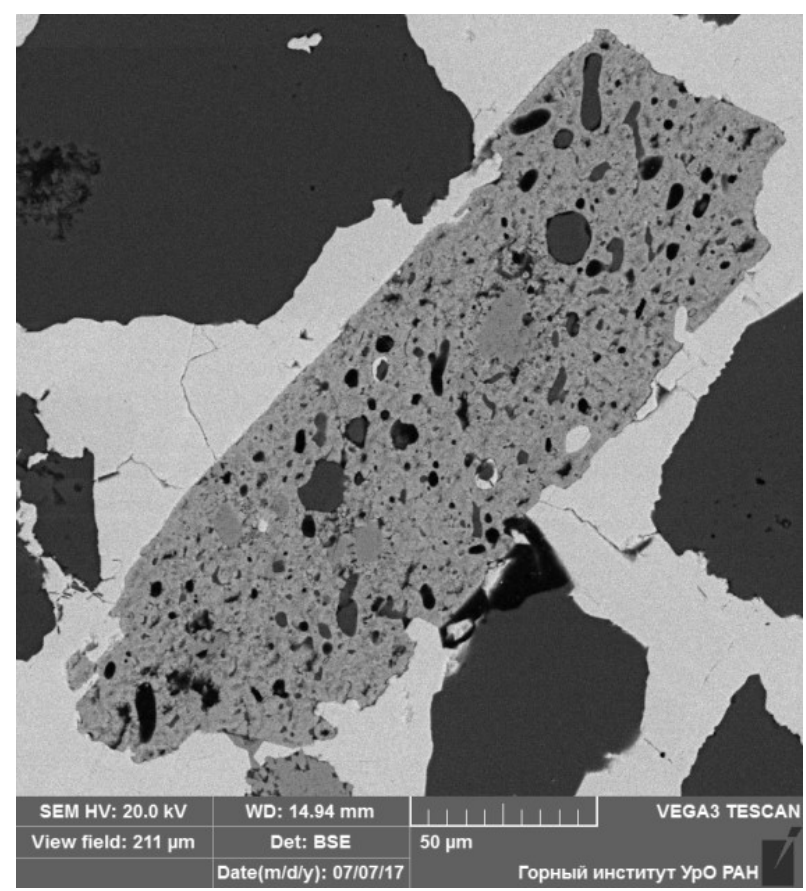

Рис. 7. Агрегат титановых минералов диоксида титана (две генерации) ильменорутила, пирита и кварца. Изображение в отраженных электронах

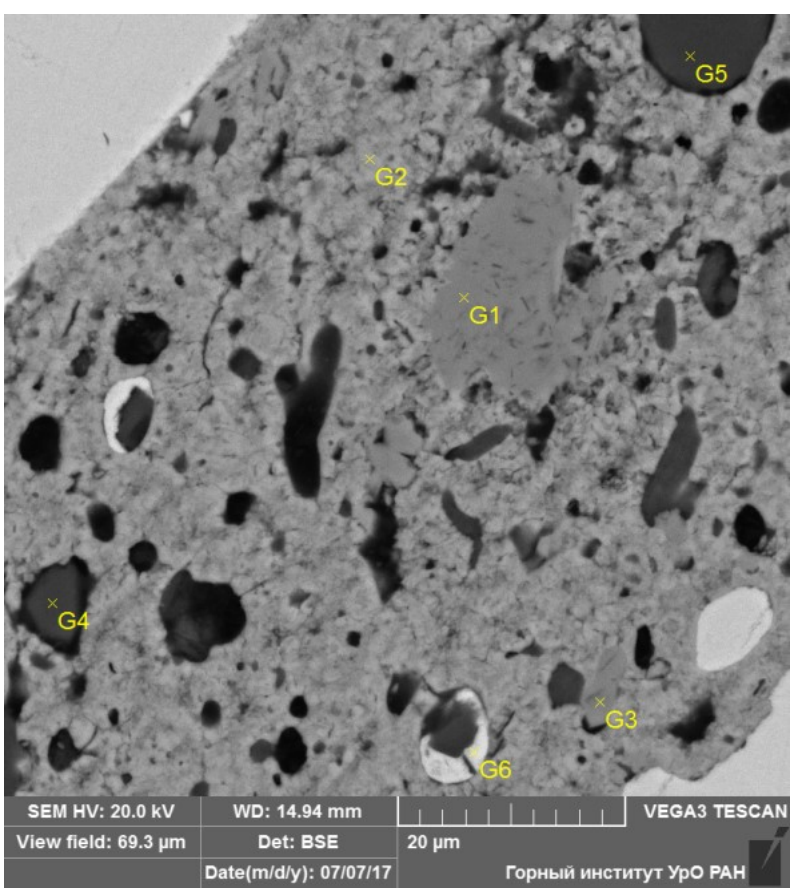

Рис. 8. Деталь: диоксид титана (G1, G3), рутил (G2), кварц (G4), кварц (G5), пирит (G6). Изображение в отраженных электронах

Микрозондовый анализ показывает наличие примесей $\mathrm{Fe}, \mathrm{Si}$ при полном отсутствии $\mathrm{Al}, \mathrm{K}, \mathrm{V}$ (табл. 1). Т.е. количество примесей в регенерированных диоксидах значительно меньше, чем в «исходном» диоксиде титана из кварц-лейкоксенового агрегата.

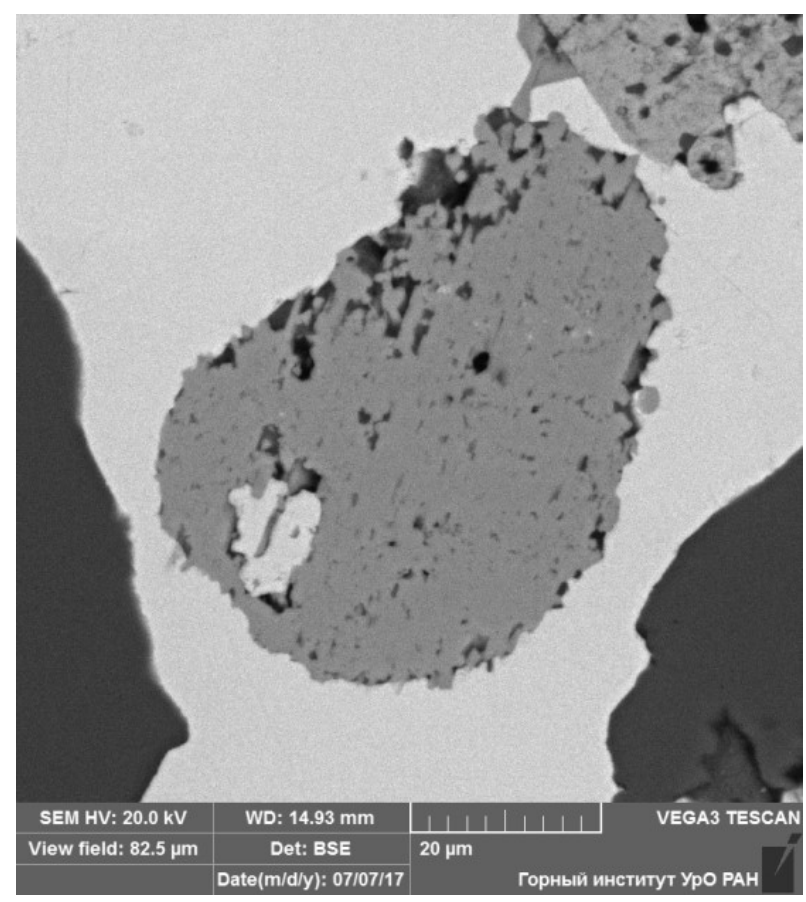

Рис. 9. Регенерированный диоксид титана (в сульфидном цементе).

Изображение в отраженных электронах

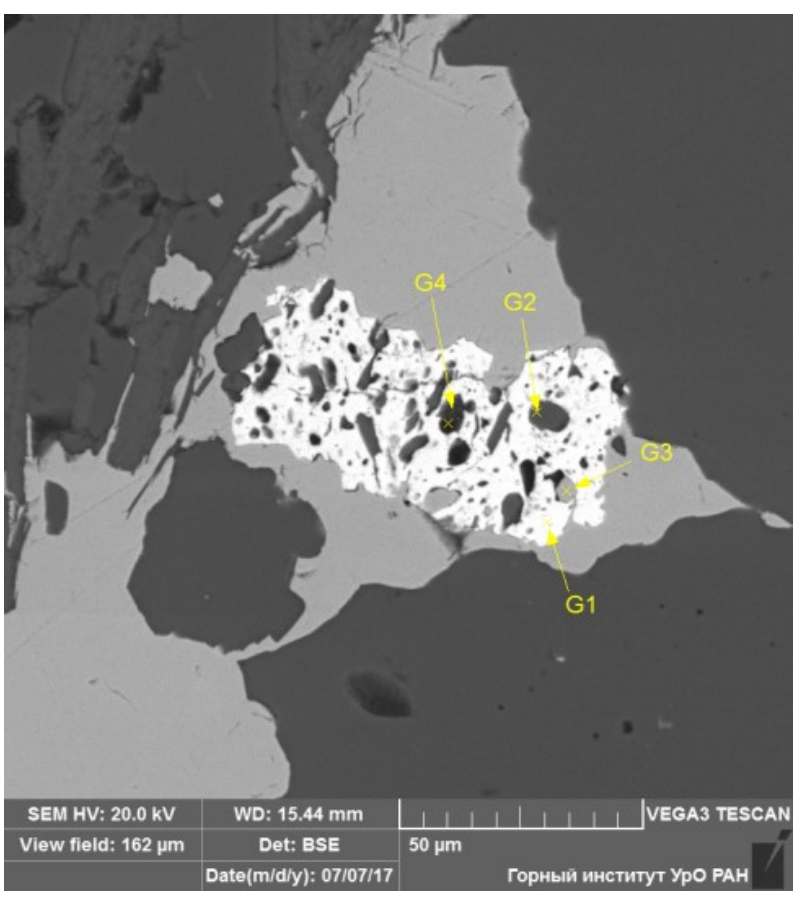

Рис. 10. Зерно монацита (G1) с кварцем (G2), пиритом (G3), органикой (G4).

Изображение в отраженных электронах 
На рис. 9 показан регенерированный (новообразованный) диоксид титана (в сульфидном цементе). Отчетливо видно отсутствие включений кварца, а микрозондовый анализ (табл. 1) показывает отсутствие примесей, характерных для диоксидов титана в «исходных» кварц-лейкоксеновых агрегатах. На рис. 10 видно зерно монацита с включениями кварца, пирита, органики.

В таблице 1 приведены анализы исходного диоксида титана (лейкоксен) и регенерированных разновидностей. Из табличных данных видно, что исходный диоксид титана содержит примеси элементов характерных для матричных (вмещающих) минералов ( $\mathrm{Si}$, Al). Анализы регенерированного диоксида титана из кварц-лейкоксенового агрегата и индивидуализированных выделений диоксида титана показывает меньшее количество таких примесей или их отсутствие. В переотложенном (новобразованном) диоксиде титана примеси отсутствуют

Состав примесей в диоксидах титана по данным МРС-анализа

Таблица 1

\begin{tabular}{|c|c|c|c|c|c|c|c|}
\hline \multirow{3}{*}{ Элементы } & \multicolumn{7}{|c|}{ Минералы } \\
\hline & \multicolumn{3}{|c|}{$\begin{array}{l}\text { Диоксид Тi } \\
\text { исходный }\end{array}$} & \multicolumn{3}{|c|}{$\begin{array}{c}\text { Диоксид Тi } \\
\text { регенерированный }\end{array}$} & $\begin{array}{c}\text { Диоксид Тi } \\
\text { новообразованный }\end{array}$ \\
\hline & \multicolumn{7}{|c|}{ Содержания, масс.\% } \\
\hline $\mathrm{O}$ & 40,77 & 38,5 & 41,14 & 40,82 & 40,17 & 41,11 & 40,91 \\
\hline $\mathrm{Ti}$ & 57,39 & 59,42 & 57,53 & 58,07 & 58,6 & 57,36 & 58,32 \\
\hline $\mathrm{Fe}$ & & 0,61 & 0,83 & 0,82 & 0,91 & 1,23 & 0,77 \\
\hline $\mathrm{S}$ & & & & & 0,32 & & \\
\hline $\mathrm{Si}$ & 1,08 & 0,63 & 0,31 & 0,3 & & 0,3 & \\
\hline \multicolumn{8}{|l|}{$\mathrm{Na}$} \\
\hline $\mathrm{K}$ & 0,21 & & & & & & \\
\hline $\mathrm{Al}$ & 0,55 & 0,56 & 0,21 & & & & \\
\hline \multicolumn{8}{|l|}{$\mathrm{Mn}$} \\
\hline \multicolumn{8}{|l|}{$\mathrm{Mg}$} \\
\hline $\mathrm{V}$ & & 0,27 & & & & & \\
\hline
\end{tabular}

Результаты свидетельствуют о существенных отличиях состава регенерированного и новообразованных диоксидов титана. Главным отличием регенерированных (новообразованных) диоксидов титана является отсутствие в них включений кварца и отсутствие примесей, характерных для исходных диоксидов титана нефтетитановых руд (табл. 1).

Процессы регенерации связаны с проявлением пострудной переработки руд в восстановительных условиях.

Особенности состава новообразованных диоксидов титана свидетельствуют о возможности разработки процесса преобразования продукта обогащении нефтетитановых руд - флотоконцентрата. Был применен высокотемпературный обжиг с использованием катализирующих добавок. Первые результаты свидетельствуют, что новообразования в обожженных образцах присутствуют. Дальнейшими экспериментами возможно вызвать эффект регенерации в кварц-лейкоксеновых агрегатах и получение диоксида титана свободного от примесей.

Эксперименты по воздействию на продукты обогащения проводились с применением фторидной технологии. Были достигнуты определенные успехи как в получении основного титанового продукта, так и в использовании отходов технологического передела в качестве сорбентов [2]. 
Нами в качестве исходного сырья для глубокой переработки использовался флотоконцентрат, полученный после переработки нефтетитановой руды.

Результаты термической переработки при помощи высокотемпературного обжига показаны на рис.11, 12, 13.

Видно, что на рис.11 и 12 характер выделения титановых минералов практически не меняется. Т.е. и исходный материал (флотоконцентртат) и материал, обожженный при температуре $600^{\circ} \mathrm{C}$ практически идентичен. Выделения не претерпели изменений в морфологии и размере выделений. Обжиг при температуре $900^{\circ} \mathrm{C}$ оказывает существенное влияние. Видны кристаллы разного размера призматического облика.

Следует вывод о возможности преобразования флотоконцентрата, полученного из нефтетитановых руд месторождения Ярега при помощи высокотемпературного обжига.

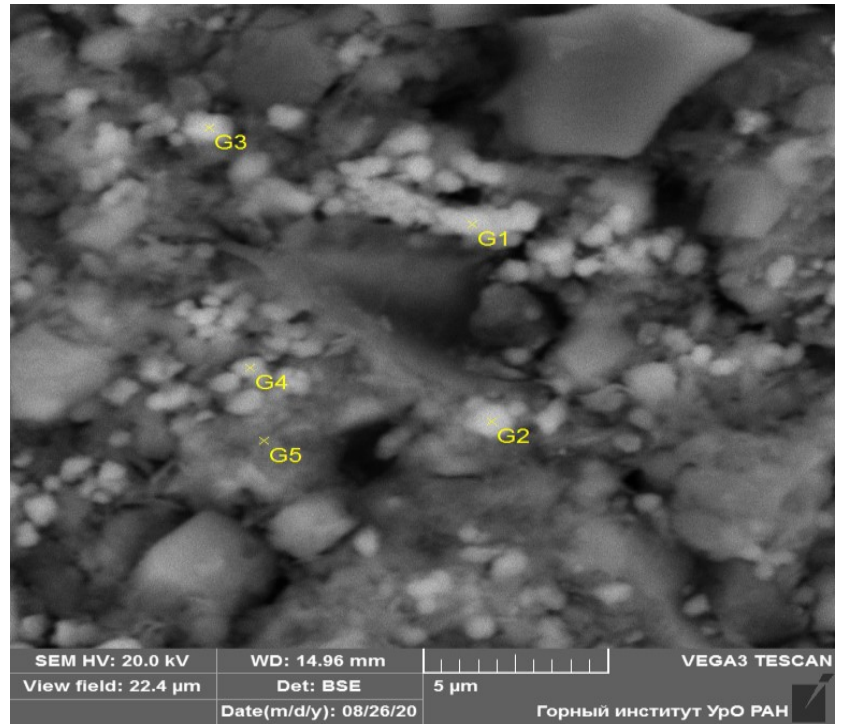

Рис. 11.

Электронное фото комбинированного шлифа изготовленного из непреобразованного флотоконцентрата. Выделения G1-G4 диоксиды титана

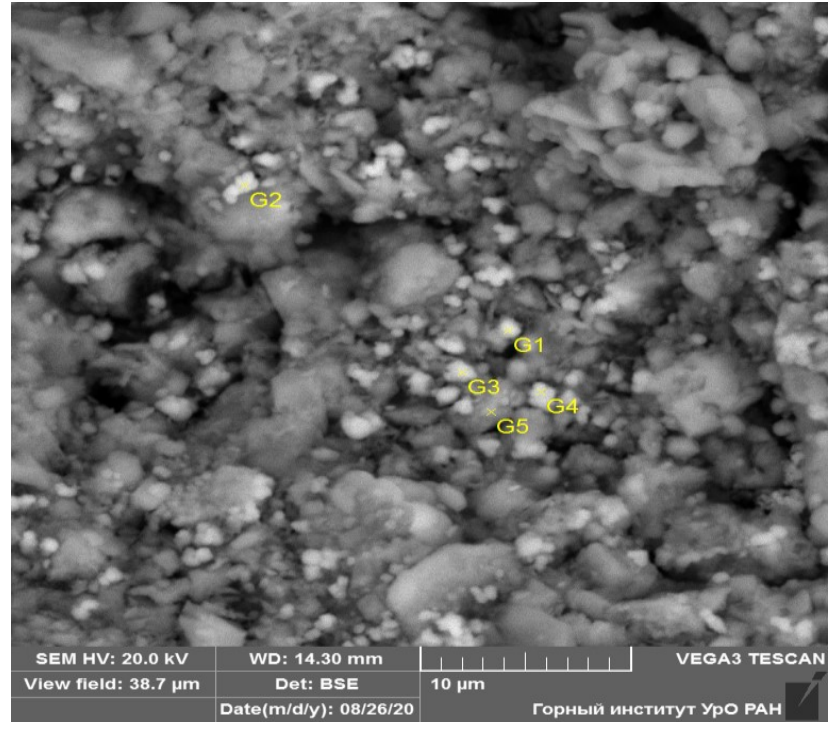

Рис. 12. Электронное фото комбинированного шлифа изготовленного из флотоконцентрата обожженного при температуре $600^{\circ} \mathrm{C}$ Выделения G1-G4 диоксиды титана

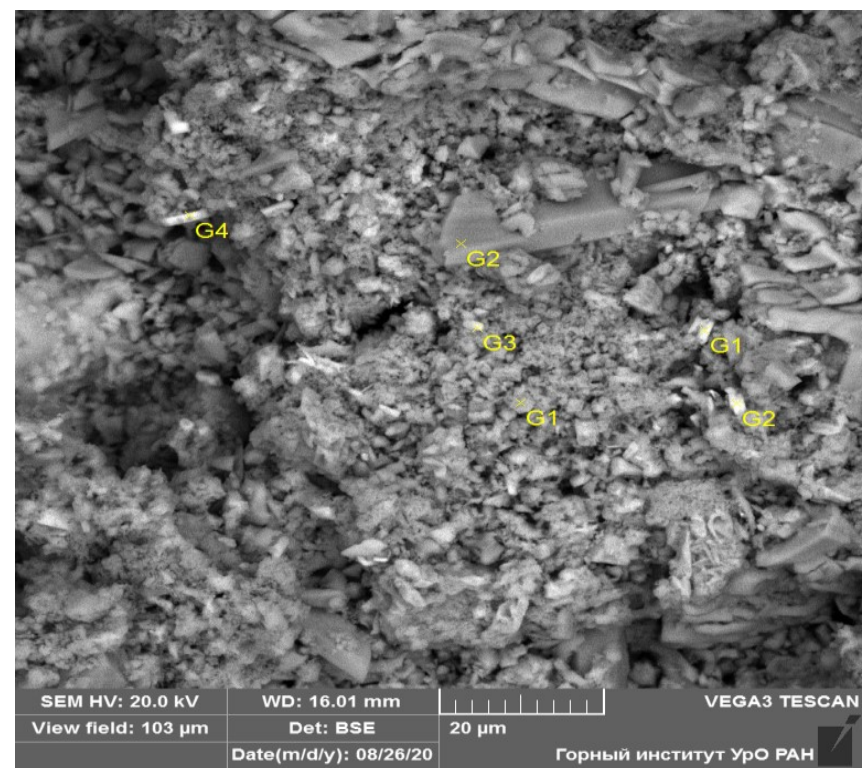

Рис. 13. Электронное фото комбинированного шлифа изготовленного из флотоконцентрата обожженного при температуре $900^{\circ} \mathrm{C}$ Выделения G1-G4 диоксиды титана 


\title{
Выводы
}

1. Исследования процессов преобразования исходных нефтетитановых руд показали наличие преобразованных в результате проявления пострудных процессов минеральных образований, по составу отвечающих диоксидам титана при полном отсутствии вростков кварца и отсутствии примесей алюминия и кремния в их химическом составе.

2. Наличие природных процессов преобразования в свою очередь позволило прогнозировать результаты техногенного воздействия на продукты обогащения нефтетитановых руд и получение продуктов, отвечающих промышленным критериям.

\section{БИБЛИОГРАФИЧЕСКИЙ СПИСОК}

1. Сметанников А.Ф., Коротченкова О.В., Оносов Д.В. Некоторые особенности минералогии нефтетитановых руд // Материалы юбилейного съезда Российского минералогического общества «200 лет РМО»: сб. тез. - Спб., 2017. - Т. 2. - С. 167-168.

2. Перовский И.А. Титаносиликаты из лейкоксеновых руд Ярегского месторождения: получение, свойства, применение: автореф. дис. ... канд. г.-м. н.: 25.00.05: / Перовский Игорь Андреевич. - Сыктывкар, 2020. -22 c.

\section{ПРИМЕНЕНИЕ СОВРЕМЕННЫХ ГИДРОДИНАМИЧЕСКИХ МОДЕЛЕЙ ДЛЯ ОЦЕНКИ ПОСЛЕДСТВИЙ КРУПНОМАСШТАБНОЙ ДОБЫЧИ ПЕСЧАНО-ГРАВИЙНОЙ СМЕСИ В НИЖНЕМ БЬЕФЕ ВОТКИНСКОЙ ГЭС}

\author{
А.А. Тиунов, А.П. Лепихин, А.А. Возняк \\ Горный институт УрО РАН, г. Пермь
}

\begin{abstract}
Аннотация: Дана оценка возможных гидравлических последствий крупномасштабной добычи песчано-гравийных смесей в верхней части Нижне-Камского водохранилища (нижнем бьефе Воткинского водохранилища) на основе проведения многовариантных вычислительных экспериментов на разработанной гидродинамической модели рассматриваемого водного объекта. Такая оценка необходима для выработки мероприятий по минимизации отрицательных последствий и обеспечении на этой основе соблюдения баланса интересов между отдельными заинтересованными водопользователями. Для оценки возможных последствий разработки новых русловых месторождений нерудных полезных ископаемых были созданы гидродинамические модели данного участка р. Камы в 1D (HEC RAS v.5.0.7) и 2D (SMS v.11.1) приближениях на основе лицензированных программных продуктов. В результате расчетов были получены графики уровней воды для различных сценариев расчета, графики сравнения уровней воды по результатам расчетов в одно- и двумерной моделей для морфометрии 2019 года в естественных условиях и с учетом выработки месторождений песчаногравийных смесей. Выполненные многовариантные вычислительные эксперименты показали, что разработка только восьми уже разрабатываемых месторождений: Волковское, Ольховское, Сивинский, Гольяновское, Макаровское, Верхне-Дулесовский, Симонихинское и Симонихинское- 2 - приведет к необходимости увеличения для поддержания судоходных глубин 3,3 м расхода сбросов в нижний бьеф Воткинской ГЭС до $1800 \mathrm{~m}^{3} / \mathrm{c}$ при продолжительности сброса 12 часов или поддержания постоянного сброса $1500 \mathrm{~m}^{3} / \mathrm{c}$ при продолжительности не менее 24 часа. Как при одномерном моделировании, так и при двумерном моделировании при сравнительном анализе графиков уровней воды можно выделить 3 участка с сильной просадкой уровня от 15 до 41 см в связи с крупномасштабной добычей ПГС.
\end{abstract}

Ключевые слова: уровенный режим водохранилища, гидродинамическое моделирование, последствия крупномасштабной добычи песчано-гравийных смесей, просадка уровня. 